Syntax Literate : Jurnal Ilmiah Indonesia p-ISSN: 2541-0849 e-ISSN : 2548-1398

Vol. 5 No. 3 Maret 2020

\title{
MANAJEMEN KOMUNIKASI OPINION LEADERS DALAM MEMBANGUN PARTISIPASI WARGA MENGELOLA KAMPUNG KB DI DESA SUKAJAYA KECAMATAN LEMBANG, KABUPATEN BANDUNG BARAT
}

\author{
Yayu Sriwartini \\ Universitas Nasional (UNAS) Jakarta \\ Email: yayu_sriwartini@yahoo.com
}

\begin{abstract}
$K B$ Village is one of the programs "Building Indonesia from the Village" by involving the role of the community to actively participate in it. However, the program has not yet succeeded in increasing citizen participation to manage KB Village optimally. Research location in Sukajaya Village with the chief informant; Secretary; People's Welfare Section; and the manager of KB Village. The research method was carried out by in-depth interviews, environmental observations and physical and digital documentation reviews. The results of the study showed that in the planning stage, opinion leaders at the village level conducted socialization through various intensive activities and events with vertical downward communication that embraced and blended. The communication pattern adopted is the wheel pattern where the opinion leader becomes the information center. Organizing, using direct communication, two-way and democratic. Opinion leaders are open and democratic, two-way communication flows and communication patterns in a circle and opinion leaders' communication styles tend to adopt The Equalitarian Style. At the implementation stage, the village government tends to apply the dynamic style of communication with the synergy of various parties. Even the village government also took part in various activities with residents. In the supervision phase, communication is carried out opinion leaders are two-way and apply a structuring style that utilizes verbal messages in writing or verbally, scheduling tasks, work, and organizational structure.
\end{abstract}

Keywords : Communication Management, Opinion Leaders, Citizen Participation

\begin{abstract}
Abstrak
Kampung KB merupakan salah satu program "Membangun Indonesia dari Desa" dengan melibatkan peran masyarakat untuk berpartisipasi aktif di dalamnya. Namun, program tersebut belum berhasil meningkatkan partisipasi warga untuk mengelola Kampung KB secara optimal. Lokasi penelitian di Desa Sukajaya dengan informan Kepala; Sekretaris; Seksi Kesejahteraan Rakyat; serta pengelola Kampung KB. Metode penelitian dilakukan dengan wawancara mendalam, observasi lingkungan serta telaah dokumentasi fisik dan digital. Hasil penelitian menunjukkan dalam tahapan perencanaan terlihat opinion leader di tingkat desa melakukan sosialisasi melalui berbagai kegiatan dan acara secara intensif dengan komunikasi vertikal ke bawah yang bersifat merangkul dan membaur. Pola komunikasi yang diadopsi adalah pola roda dimana opinion leader yang menjadi
\end{abstract}


pusat informasi. Peng-organisasian, menggunakan komunikasi langsung, dua arah dan demokratis. Opinion leader bersikap keterbukaan dan demokratis, aliran komunikasi bersifat dua arah dan pola komunikasi berbentuk lingkaran serta gaya komunikasi opinion leader cenderung mengadopsi The Equalitarian Style. Pada tahap pelaksanaan, pemerintah desa cenderung menerapkan gaya komunikasi dinamyc style dengan bersinergi berbagai pihak. Bahkan pemerintah desa pun turut andil dalam berbagai kegiatan bersama warga. Tahap pengawasan, komunikasi dilakukan opinion leader bersifat dua arah, dan menerapkan gaya structuring style yang memanfaatkan pesan-pesan verbal secara tertulis ataupun lisan, penjadwalan tugas, pekerjaan, serta struktur organisasi.

Kata kunci: Manajemen Komunikasi, Opinion Leaders, Partisipasi Warga

\section{Pendahuluan}

Dunia bisnis modern, baik yang berskala kecil, menengah dan besar, tidak akan bisa lepas dari yang namanya komunikasi termasuk dalam pembangunan (Yuswanto, 2018). Pembangunan merupakan salah satu upaya untuk menuju perubahan yang lebih baik dari berbagai aspek. Pemerintah melalui Bappenas telah mengusulkan lima prioritas nasional dalam Rancangan Awal Rencana Kerja Pemerintah (RKP) untuk tahun 2019, yang bertujuan untuk menekan angka kemiskinan dan meningkatkan kesejahteraan hidup masyarakat Indonesia secara menyeluruh baik perkotaan maupun di pedesaan yaitu:

Pertama, Pembangunan manusia melalui pengurangan kemiskinan dan peningkatan pelayanan dasar; Kedua, Pengurangan kesenjangan antarwilayah melalui penguatan konektivitas dan kemaritiman; Ketiga, Peningkatan nilai tambah ekonomi melalui pertanian, industri, dan jasa produktif; Keempat, pemantapan ketahanan energi, pangan, dan sumber daya air; Kelima, stabilitas keamanan nasional dan kesuksesan pemilihan umum (Wicaksono, 2018).

Keputusan Pemerintah Jokowi-JK untuk membangun Indonesia bermula dari desa, oleh karena itu berlimpah program yang menyasar ke pedesaan, salah satunya adalah Program Kampung Keluarga Berencana $(\mathrm{KB})$ yang dicanangkan Presiden Joko Widodo pada 16 Januari 2016, dan pada tahun 2018 sudah mencapai 8.112 Kampung KB di seluruh Indonesia (Tempo.co, 2018).

Sampai tahun 2018 Provinsi Jawa Barat telah berhasil melahirkan lebih dari 1.300 Kampung KB dan menjadi percontohan bagi provinsi lain dalam program menekan laju pertumbuhan penduduk (Pemerintah Provinsi Jawa Barat, 2018), namun demikian salah satu fokus perhatian peneliti ada yang belum berhasil secara optimal diantaranya Kampung KB yang berada di RW 06 Desa Sukajaya, Kecamatan Lembang, Kabupaten Lembang Barat yang bernama Kampung KB Insan Sejahtera.

Mewujudkan kesejahteraan melalui berbagai program kegiatan tidaklah mudah. Perlu ada sinergi antara pemeritah, masyarakat (warga) serta berbagai Lembaga sosial di masyarakat (Sabarisman, 2015). Terutama para warga yang menjadi sasaran program, perlu dipersuasi agar aktif terlibat di dalamnya (Padmiati, 2013). Di sini peran 
kepemimpinan aparat daerah sangat penting dalam manajemen pelaksanaan Kampung KB Insan Sejahtera. Sebagaimana dipaparkan (Azizah, 2019) bahwa dalam pengelolaan program Kampung KB diawali dengan perencanaan yang dilaksanakan oleh pengurus dan kegiatan yang dilaksnakan diantaranya perumusan tujuan, identifikasi masalah dan penentuan progam.

Namun dalam implementasinya, pencapaian tujuan tugas dan tanggung jawab negara masih dirasakan belum mencapai hasil yang optimal. Hal ini ditunjukkan dengan masih rendahnya angka partisipasi warga atau masyarakat dalam menunjang program Kampung KB karena masih terdapat 2,5\% rumah tangga sasaran yang mempunyai kategori sangat miskin (RTSM) yang masih perlu mendapat perhatian dan penanganan secara maksimal.

Selanjutnya pengorganisasian yang didalamnya menentukan struktur kepengurusan dan pemberian tugas dan fungsi kepada para pengurus, selanjutnya penggerakan partisipasi masyarakat dan evaluasi untuk mengetahui keberhasilan suatu program. Fokus penelitian terdahulu ini pada kepemimpinan kolektif yang dilaksanakan secara integrative. Di luar itu, peneliti melihat bahwa persoalan komunikasi sangat penting di dalam menggerakkan para warga untuk berpartisipasi aktif. Oleh karena itu rumuan masalah yang diajukan adalah bagaimana manajemen komunikasi opinion leader dalam membangun partisipasi warga mengelola Kampung KB Insan Sejahtera?

\section{Metode Penelitian}

Metode kualitatif, menurut (Bogdan \& Taylor, 1992), adalah prosedur penelitian yang menghasilkan data deskriptif berupa kata tertulis atau lisan dari orang-orang dan perilaku yang dapat diamati. Pendekatan ini dapat diarahkan pada latar dan individu tersebut secara utuh Jadi, tidak boleh mengisolasikan individu atau organisasi ke dalam variable atau hipotesis, tapi perlu memandangnya sebagai bagian dari suatu keutuhan (Bryman, 2016). Sementara itu, penelitian kualitatif adalah tradisi tertentu dalam ilmu pengetahuan sosial secara fundamental bergantung pada pengamatan pada manusia dalam kawasannya sendiri dan berhubungan dengan orang-orang tersebut dalam bahasa dan peristilahannya (Moleong Lexi, 2000). Peneliti menggunakan penelitian kualitatif karena dalam penelitian ini membahas mengenai pola strategi komunikasi orangtua pada anak di era digitalisasi. Semua fakta atau fenomena-fenomena sosial, serta pengamatan dilapangan peneliti lakukan baru kemudian menganalisisnya berdasarkan apa yang diamati. Teknik Pengumpulan Data menggunakan wawancara dan Telaah dokumentasi fisik dan digital.

Uji analisis data menggunakan metode kualitatif murni dengan penyajian data dalam bentuk narasi yang disusun secara sistematis, dan dikuatkan oleh kutipan-kutipan langsung dan tidak langsung dari para informan serta sumber-sumber data sekunder lainnya (Creswell \& Creswell, 2017). Selain narasi disajikan pula bentuk bagan yang memberikan gambaran tentang model manajemen komunikasi pemerintah desa dalam membangun partisipasi warga mengelola Kampung KB Insan Sejahtera Desa Sukajaya, 
kemudian data dianalisis dari perspektif manajemen komunikasi, pola aliran informasi, serta gaya komunikasi.

\section{Hasil dan Pembahasan}

Seiring dengan berkembangnya kemajuan di berbagai bidang, pelayanan kesejahteraan sosial dirasakan oleh masyarakat masih kurang optimal dalam memberikan bantuan untuk mengatasi berbagai permasalahan sosial, dimana pelayanan kesejahteraan sosial harus dilakukan secara terpadu dan berkelanjutan, menjangkau seluruh warga yang mengalami masalah sosial, menggunakan sistem dan program yang melembaga dan profesional, mengedepankan peran dan tanggung jawab keluarga serta masyarakat yang dituangkan dalam Rencana Pembangunan Jangka Panjang, Rencana Pembangunan Jangka Menengah Nasional serta Rencana Strategis.

Mengingat kompleksitas permasalahan sosial maka idealnya penanganannya harus dilakukan secara terintegrasi dan terpadu, lintas sektor, lintas pelaku. Disamping itu, di era otonomi daerah ini, pelayanan sosial harus lebih menjangkau masyarakat di tingkat akar rumput. Seperti yang dikatakan (Nasirin, 2010) mengindikasikan pada era otonomi daerah masalah kesejahteraan sosial sebagai indikasi rendahnya kualitas sumber daya manusia masih menjadi permasalahan besar, jika tidak cepat dientaskan akan menjadi boomerang dalam kehidupan bernegara. Konsekuensinya bagi pemerintah pusat maupun pemerintah daerah harus lebih mengenali dan memahami permasalahan sosial di daerahnya, sekaligus mampu memberikan solusi layanan yang dibutuhkan masyarakatnya, secara tepat, cepat, efektif dan efisien serta terintegrasi.

Berkaitan dengan pencapaian komunikasi secara efektif dan efisien kepada masyarakat maka menurut (Pace et al., 2000) ada hal-hal yang perlu dipahami dalam kajian struktur komunikasi dalam organisasi yaitu kemanakah arah atau arus komunikasi dalam organisasi. Terdapat beberapa pandangan alternatif dalam memamahami organisasi, pertama realitas sosial dan bagaimana kita memahami dunia sosial kita. Perilaku dan objek adalah konstruksi sosial, karena bergantung pada manusia untuk membuat perilaku dan objek itu signifikan, karena suatu objek sosial sekadar objek yang mempunyai makna bagi suatu kolektivitas atau menuntut tindakan manusia. Objektif merujuk pada pandangan bahwa objek-objek, perilaku-perilaku, dan perisitiwa-peristiwa eksis dalam masyarakat. Sedangkan subjektif menunjukkan bahwa realitas itu sendiri adalah suatu konstruksi sosial.

Penelitian ini mengambil data dari beberapa informan yang dianggap sebagai opnion leader baik dari kalangan pemerintah daerah maupun masyarakat yang menjadi pengurus atau pengelola Kampun KB. Menurut Windra, Kepala Seksi Pemerintahan Desa Sukajaya sekaligus key informan, bahwa sebelum Kampung KB dibentuk pada tanggal 7 Juni 2017, pihak Pemerintah Desa Sukajaya terlebih dahulu melakukan sosialisasi secara bertahap mulai dari tingkat desa, RW dan RT. Semua aparat desa turut terlibat dalam sosialisasi, termasuk kepala desanya sendiri. Begitu pula para pengelola PKK, Pos KB serta Petugas Lapangan KB. 
Esensi dari Program Kampung KB yang disosialisasikan kepada masyarakat dan lembaga kemasyarakatan adalah tidak hanya membahas tentang Keluarga Berencana, tapi juga mengenai 8 fungsi lainnya yakni fungsi Agama, fungsi Reproduksi, fungsi Ekonomi, Sosial dan Pendidikan, Keamanan, Cinta dan Kasih sayang, Perlindungan dan Lingkungan. Setelah sosialisasi dilakukan dan semua masyarakat mengetahuinya, langkah berikutnya adalah pemerintah desa membentuk pengelola dan pengurus. Menurut Wini, Sekretaris Seksi Pemerintahan (Kasi) sekaligus pengelola Kampung $\mathrm{KB}$, dari sejak sosialisasi sampai pembentukan pengurus, setidaknya pemerintah desa sudah mengadakan rapat dengan para tokoh RW sebanyak tiga kali.

Pengurusnya merupakan masyarakat setempat yang dipilihnya secara musyawarah, melalui rapat bersama kepala desa juga, dan ditanyakan kesediaannya, orang tersebut itu bersedia atau tidal menjadi pengurus atau dicalonkan begitu ya, jadi kita tetap tanya dulu, jangan istilahnya main tunjuk begitu, jadi kesediaannya atas dasar kesadaran dia sendiri apakah mau jadi pengurus atau tidak dengan tugas-tugas dan tanggungjawabnya itu.

Pembentukan pengelola dan pengurus tersebut disahkan oleh kepala desa. Artinya para pengurus memiliki SK. Baik Windra maupun Wini mengakui bahwa tidak ada kesulitan atau hambatan pada saat menyosialisasikan Program Kampung KB, sebab sebelumnya sudah melaksanakan Program Gempungan dari Pemerintah Kabupaten. Gempungan merupakan salah satu Program KKBPK yang bertujuan mengentaskan kemiskinan.

Jadi dari awalnya Gempungan itu, kita tidak terlalu susah ke Kampung KB, program Gempungan itu juga hanpir sama dengan Kampung KB, jadi waktu kita membentuk kepengurusan untuk Kampung KB ya udah ada personilnya dari Program Gempungan itu, jadi ketika disosialisasikan Kampung KB, mereka sudah tidak kaget ya. Tapi awalnya kaget juga, karena mikir gitu apakah semuanya harus ber-KB gitu ya, padahal bukan seperti itu. (Key informan)

Masyarakat pun memberikan respon yang bagus, sebab dengan adanya Program Kampung KB, kegiatan masyarakat menjadi lebih banyak,

Seperti tadi yang dijelaskan ada 8 fungsi, semuanya fungsi tersebut memang harus berjalan. Contohnya untuk lingkungannya rumah warga itu ditanam tanaman Toga dan sayuran-sayuran, nantinya mungkin bisa menjadi tambahan nilai ekonomi, ada Bawang Daun, Tomat, Tauge, mudah-mudahan ke depannya kalau jumlah produksinya banyak bisa dijual dan dikelola sama Kampung KB, itu tujuannya.

Kembali kepada pembentukan pengelola dan pengurus, setelah disahkan oleh kepala desa, dan mereka mendapatkan SK, mereka langsung bekerja melaksanakan ke delapan program tersebut. Namun demikian menurut key informan, adanya SK tidak berimplikasi pada honor.

Untuk saat ini belum ada, karena hal itu memang sudah menjadi partisipasi mereka. Untuk insentif dan honor itu tidak ada, namun dari desa itu sudah ada 
bantuan ke Kampung KB pada tahun 2018 lalu (APBDes) itu mengeluarkan 10 Juta selama 1 tahun. Alat pembantu administrasi, Papan data juga kita bagikan kesana, bibit-bibit tanaman juga sebagian dari desa, dari Kabupaten juga kemarin dapat Dana hibah, itu digunakan untuk Bale Sawala, yaitu tempat balai musyawarahnya mereka, istilahnya sekretariat pengelolanya.

Pelaksanaan program Kampung KB, masyarakat selalu didampingi oleh aparat pemerintah baik dari Satuan Kerja Perangkat Daerah (SKPD) tingkat desa maupun tingkat kecamatan. Ini bentuk tanggung jawab pemerintah di dalam menyukseskan tercapainya tujuan Kampung KB. Oleh karena itu pendampingan pun dilakukan setiap saat, tidak terbatas waktu. Untuk mengoptimalkan pelaksanaan berbagai program, pemerintah Desa Sukajaya pun bersinergi dengan berbagai instansi pemerintah lainnya seperti Dinas Sosial, Dinas Perindustrian, Dinas Seni dan Budaya, sebab instansi tersebut pun memiliki program yang dapat sinergikan. Misalnya Dinas Sosial memiliki Program Membantu Rumah Tidak Layak Huni, dan Kampung KB menjadi sasaran utamanya.

Sementara itu dalam proses pelaksanaan program-program Kampung KB Insan Sejahtera, beberapa opinion leader yang merupakan pengurus inti memberikan penjelasannya sebagai berikut: Pertama, Program Toga yakni program lingkungan. Menurut Inge Kusuma, Sekretaris Kampung KB, program tersebut sudah berjalan selama 3 tahun. Bentuknya berupa penanaman berbagai jenis tanaman kebutuhan warga yang memanfaatkan pekarangan rumah. Sebelumnya warga diberi keterampilan bercocok tanam dengan menggunakan kantong plastik dan bambu. Tujuan awalnya adalah untuk memanfaatkan lahan kosong di setiap rumah sehingga menjadi produktif. Jika ternyata hasilnya banyak, warga bisa menjualnya. Selain itu penataan halaman pun menjadikan halaman rumah menjadi rapi dan indah. Program lainnya adalah bersihbersih lingkungan setiap hari minggu yang dinamakan "Minggu Bersih". Kegiatan ini diikuti oleh seluruh warga, pengurus bahkan aparat desa. Kegiatan lainnya dalam Program Pembinaan Lingkungan adalah bergotong royong merenovasi kamar mandi umum yang biasa digunakan masyarakat sekitar.

Menurut Rahman Hidayat yang merupakan ketua seksi lingkungan, "Jumlah anggota yang aktif dalam kegiatan tersebut ada sekitar 30-50 tapi karena kurangnya dana atau modal maka kami hanya memperaktekan di halaman rumah kami masingmasing dengan alat dan bahan seadanya atau sewadaya,". Namun demikian Rahman menyampaikan bahwa pemerintah desa mendukung kegiatan tersebut dengan memberi anggaran untuk membeli bibit, meski belum maksimal. Untuk mendorong partisipasi warga, pengurus yang didukung oleh Pemerintah Desa mewajibkan setiap rumah menanam berbagai tanaman keperluan rumah tangga dengan memanfaatkan lahan yang ada semaksimal mugkin.

Kemudian dalam pelaksanaan kegiatan keagamaan, menurut Cecep Saepudin telah dibuatkan jadwal pengajian untuk bapak-bapak yang mendatangkan penceramah satu bulan. Di samping itu ada juga program belajar al-quran untuk ibu-ibu seminggu sekali, anak-anak setiap sore, untuk remaja dan bapak-bapak setiap sore dan selepas 
maghrib. Untuk operasional pengajian ini didanai dari kas masjid, infaq serta swadaya warga. Saat ini kegiatan tersebut berjalan lancar, dan aparat desa pun terkadang mengingkuti kegiatan pengajian sebulan sekali. Cecep menuturkan jika masyarakat cukup semangat dan atusias untuk mengikuti kegiatan pengajian ini bahkan ada sekitar 30 remaja yang aktif, mereka membagi kelompok dan membuat divisi sendiri. Tujuan dari program pengajian ini adalah untuk mengentaskan buta huruf terhadap Al Qur'an. "Sejatinya sebagai warga yang dominan beragama beragama islam, sudah kewajiban untuk bisa membaca dan menulis Al Qur'an," pungkas Cecep.

Sementara dalam mengembangkan program kesenian, Cucu Hidayat selaku ketua Divisi Sosial Budaya mengatakan bahwa kesenian yang dikembangkan di Kampung KB berupa gotong singa, pancak silat, calung, kuda lumping, marawis. Serta biasanya kesenian kuda lumping digunakan untuk acara agustusan. Ada sekitar 200 warga mulai dari anak-anak, remaja sampai orang dewasa yang terlibat aktif dalam mengikuti kegiatan kesenian tersebut. Kesenian-kesenian tersebut sudah ada sejak tahun 1990 dan merupakan kesenian khas Bandung. saat ini dikembangkan kembali di Kampung KB agar tetap terjaga eksistensinya. Selain itu agar Kampung KB Desa Sukajaya Kecamatan Lembang lebih terangkat. Cucu mencontohkan salah satu prestasi yang dicetak melalui kesenian tersebut adalah Desa Sukajaya meduduki juara ketiga seProvinsi Jawa Barat dalam acara kesenian sosial dan budaya tahun 2018. "Dana untuk proram ini tentu saja ada bantuan dari pemerintah untuk peralatan kesenian yang sudah tidak layak pakai dan untuk seragam anggota, serta ada iuran untuk setiap acara yang ada di kampung kb desa sukajaya," ujarnya.

Dalam Program Sosial Budaya ini dikembangkan tradisi "Botram Liwet Bala", yakni makanan khas Kampung KB Insan Sejahtera, makanan ini biasanya disajikan pada saat selesai kegiatan baik pada saat ada kunjungan tamu, kegiatan keagamaan, kegiatan kesenian, malam resepsi, dan kegiatan-kegiatan lainnya yang biasa dilaksanakan di Kampung KB Insan Sejahtera. Diharapkan dengan kegiatan botram (makan bersama) dapat membuat silaturahmi semakin erat dan kompak.

Program berikutnya adalah Kampung Peduli ini yakni program perlindungan yang dilakukan oleh masyarakat di kampung KB untuk membangun kepedulian terhadap kampung KB itu sendiri. Seperti peduli terhadap sampah yang ada disekitarnya,lalu peduli terhadap kesehatan seperti tidak merokok di dalam ruangan. Menurut Liani Ketua Seksi Reproduksi yang melahirkan program Kampung Peduli, semua masyarakat di sini harus mengikuti program Kampung Peduli, "saat ini sudah ada 2 RT warga yang turut berpartisipasi dalam program ini,”. Menurutnya masih perlu upaya yang keras untuk membujuk para warga memiliki kesadaran untuk menjaga lingkungan. Sebagai contoh masih ada saja warga yang suka menumpuk-numpuk sampah, sehingga menimbulkan aroma tidak sedap bagi lingkungan sekitar. Selama ini pengumpulkan sampah dikoordinir oleh seksi lingkungan.

Lalu ada juga Program Cinta Kasih (Kasih Sayang) yang bertujuan mengajarkan anak untuk bersosialisasi, menumbukan motorik anak serta menghindari kekerasan dalam rumah tangga kepada anak. Bentuk kegiatan ini dengan cara mendongeng, 
memberikan mainan kepada anak, menggambar dan memberi penyeluhan tentang kekerasan dalam rumah tangga (KDRT). Target ke depan membuat tempat bermain khusus program cinta kasih dan ingin menambah fasilitas bermain dan belajar seperti mainan,buku gambar dan buku cerita. Namun menurut Inge, ketika aka nada kegiatan maka penyampaian informasinya harus jauh-jauh hari. Selain itu ada pertemuan rutin yang dilakukan pengurus dengan ibu-ibu tujuannya untuk menjalin komunikasi dari tim Bina Keluarga Remaja (BKR) Kampung KB Insan Sejahtera kepada para ibu-ibu yang memiliki remaja.

Selanjutnya adalah Program kampung bekerja dan produktif. Program ekonomi ini sudah mulai berjalan sejak setelah diresmikan kampung KB yaitu pada tahun 2017. Tujuan dari kegiatan ini adalah untuk membantu memperbaiki perekonomian serta memberikan dan menyediakan lapangan pekerjaan bagi masyrakat di Desa Sukajaya. Menurut Yayat Sutaryat (Ketua Seksi Sekonomi), untuk sementara di Kampung KB baru menyediakan program keterampilan daur ulang sampah dan program dana ekonomi bergulir yang baru berjalan sekitar dua tahun, diharapkan dapat berkelanjutan. Harapannya dengan kegiatan ini dapat membangun kesadaran masyrakat untuk ikut berpartisipasi. Program ini didukung oleh Pemerintah Desa dengan memberikan dana ekonomi bergulir sebesar Rp. 10.000.000.00 kepada 10 orang yang dipilih dan dianggap bisa mengelolanya. Jadi masing-masing mendapatkan sebesar 1 juta Sedangkan untuk program daur ulang sampah dana dari hasil sewadaya masyrakat.

Keuntungan dari kegiatan ini adalah bisa memperbaiki ekonomi masyrakat dan menajaga kebersihan serata meminimalisir sampah. Serta masyrakat berhasil membangun balai pertemuan dengan adanya program kampung berkerja tersebut, jadi dalam kegiata tersebut masyrakatyang memiliki kemampuan seperti tukang kayu, tukang batu dan lainnya menyumbangkan tenaganya untuk membangun balai pertemuanya pada waktu senggang. (Informan: Yayat)

Kegiatan ini masyarakat dididik untuk mendaur ulang sampah plastic menjadi sebuah karya seni dan ada juga yang membuat pupuk. Sedangkan masyarakat yang dipilih menerima dana ekonomi bergulir diberi kesempatan membuka warung dan mengelolanya. Untuk kegiatan daur ulang sampah ada sekitar 20 orang sedangkan program dana bergulir hanya ada 10 orang saja dikarenakan mimimnyadan kurangnya dana.

Pemerintah desa melakukan peninjauan setiap saat. Dijelaskan key informan bahwa dalam melakukan pembinaan, pemerintah bekerjasama dengan pendamping dari tingkat kecamatan serta tingkat kabupaten. Selain itu pemerintah desa pun berkoordinasi dengan pengelola dan pengurus Kampung KB untuk memastikan berbagai perkembangan partisipasi masyarakat pada delapan program. Untuk memotivasi masyarakat agar berpartisipasi aktif, pemerintah desa serta pengurus Kampung KB tidak henti-hentinya melakukan sosialisasi. Misalkan pada saat kegiatan pengajian atau pertemuan-pertemuan dengan warga, selalu disisipi dengan berbagai informasi tentang 
program, bahkan seringkali pertugas mendatangi warga ke rumahnya, melakukan pendekatan sambil melakukan pendataan.

Memang tidak mudah membujuk warga untuk berpartisipasi aktif, menurut informan tidak sedikit warga yang sudah tahu Program Kampung KB tetapi acuh tidak acuh. Oleh karena itu salah satu cara konkrit yang sederhana untuk membangun kesadaran bertenggang rasa dan cinta kasih adalah menggalakkan kembali program "Perelek Beras".

"Perelek beras" diambil dan dikumpulkan oleh pengurus Kampung KB, kemudian dialokasikan pada masyarakat yang kurang mampu atau yang lebih membutuhkannya. Misalkan berbentuk beras, bukan berbentuk uang, kita simpan di tempat semacam "Bamu", kemudian diambil satu Minggu Satu kali, ada beras yang terkumpul sudah berapa kilo, dialokasikan kepada warga yang butuh. Atau bisa juga kayak ada kegiatan Isra Mi'raj, Muharram-an, itu kadang dibuat seperti konsumsi makanan, berasnya dipakai untuk itu. Kalau ada yang meninggal juga, kadang dialokasikan untuk itu."

Selama ini program tersebut yang merupakan bagian dari fungsi lingkungan, sudah cukup berhasil, bahkan merupakan salah satu ciri khas dari Kampung KB di RW 6 ini. Menurut key informan, program lingkungan merupakan salah satu yang banyak diikuti oleh masyarakat. Selain itu ada juga kegiatan kerja bakti yang dilakukan setiap satu minggu sekali. Bahkan aparat desa pun seringkali berpartisipasi bergabung Bersama warga. Hal ini dilakukan sebagai bentuk pengawasan juga terhadap keterlibatan warga dalam mewujudkan delapan fungsi program KB.

a) Program kesehatan; masyarakat terutama yang memiliki balita juga sudah terdorong untuk mengikuti kegiatan pemeriksaa rutin satu bulan sekali Sudah banyak kesadaran orangtua untuk mengikut sertakan anak-anaknya ke program. Kampung KB pun memiliki program penyuluhan kesehatan yang mendatangkan informan dari kecamatan. Informan pun menjelaskan dalam fungsi lainnya, seperti Reproduksi itu juga pengurus juga memfasilitasi Safari KB dalam bentuk membantu menyewakan angkutan umum (angkot) jika ada masyarakat yang mau ke Puskesmas, atau bisa juga di Rumah Sakit Ciembeuluit. Kita fasilitasi seperti MOV, MOW di rumah sakit, sedangkan dari desa itu difasilitasi sewa angkot (ambulance), untuk uang pendaftarannya, gratis, dan didampingi juga dengan kader-kadernya. Kegiatan tersebut biasa dilakukan 4 sampai 5 kali dalam satu tahun. Program ini juga melibatkan para elit desa dan pengurus PKK.

b) Bidang Pendidikan; pengurus pun memantau kondisi Pendidikan anak-anak di wilayah RW 6, jika ada anak yang putus sekolah, maka akan diikutsertakan dalam program kejar paket C. Tentu program tersebut difasilitasi pihak desa yang bekerjasama dengan Dinas Pendidikan Bandung Barat. "cara memantaunya dengan mendata anak-anak yang putus sekolah dalam setiap bulan," Pada intinya tujuan Kampung KB adalah mewujudkan delapan (8) fungsi keluarga. Pelaksanaan program-progamnya tidak ada Batasan waktu, "pokoknya sampai tujuan mengentaskan kemiskinan tercapai. Menurut key informan yang lain, pelaksanaan 
Kampung KB ke depan tidak hanya sebatas di RW 06 saja, tetapi akan diupayakan satu desa, "lingkupnya bukan RW lagi, tapi skala desa, jadi se-desa itu masuk Kampung KB , itu arahan dari pusat."

Hal tersebut di atas, bertujuan untuk memantau kemajuan terimplementasikannya delapan fungsi keluarga dengan baik, pihak desa pun selalu rutin melakukan pengawasan setiap satu bulan sekali. Bahkan para pengurus pun seringkali berinisiatif memberikan pelaporan berbagai kegiatan baik secara formal maupun informal. Dari laporan pengurus itu, pihak desa meneruskannya ke Unit Pelaksana Teknis (UPT) kecamatan. Hubungan antara pengurus Kampung KB dengan pihak desa berjalan dengan baik dan saling responsif, sebab kedua belah pihak selalu komunikatif dan koordinatif. Bahkan sesama pengurus pun saling bahu membahu, saling tolong menolong.

Selain melakukan pengawasan, pihak desa pun melakukan evaluasi terhadap pelaksanaan program. Hal ini dilakukan untuk mengetahui apakah tujuan program sudah tercapai atau belum. Jika belum warga belum mendapatkan pendampingan yang maksimal, maka diberikan lagi pendampingan yang ekstra serta meningkatkan lagi kualitas pengetahuan dan keterampilan warga dengan penambahan berbagai pelatihanpelatihan, Bahkan untuk pelatihan diberikan pula kepada pengurus, supaya berikutnya pengurus bisa memberikan pelatihan kepada warga untuk pelatihan membuat kue atau sosialisasi tentang kekerasan dalam rumah tangga (KDRT).

Tabel 1

Mekanisme operasional Kampung KB Insan Sejahtera

\begin{tabular}{lcc}
\hline \multicolumn{1}{c}{ Kegiatan } & Pelaksanaan & Frekuensi \\
\hline Rapat perencanaan kegiatan & Ada & Bulanan \\
\hline $\begin{array}{l}\text { Rapat koordinasi dengan dinas/instansi terkait } \\
\text { pendukung kegiatan }\end{array}$ & Ada & Bulanan \\
\hline Sosialisasi kegiatan & Ada & Bulanan \\
\hline Monitoring dan evaluasi Kegiatan & Ada & Bulanan \\
\hline Penyusunan laporan & Ada & Bulanan \\
\hline
\end{tabular}

Sumber: http://kampungkb.bkkbn.go.id/kampungkb/profile/6628, Tahun 2019 
MODEL MANAJEMEN KOMUNIKASI PEMERINTAH DESA DALAM MEMBANGUN PARTISIPASI WARGA MENGELOLA KAMPUNG KB
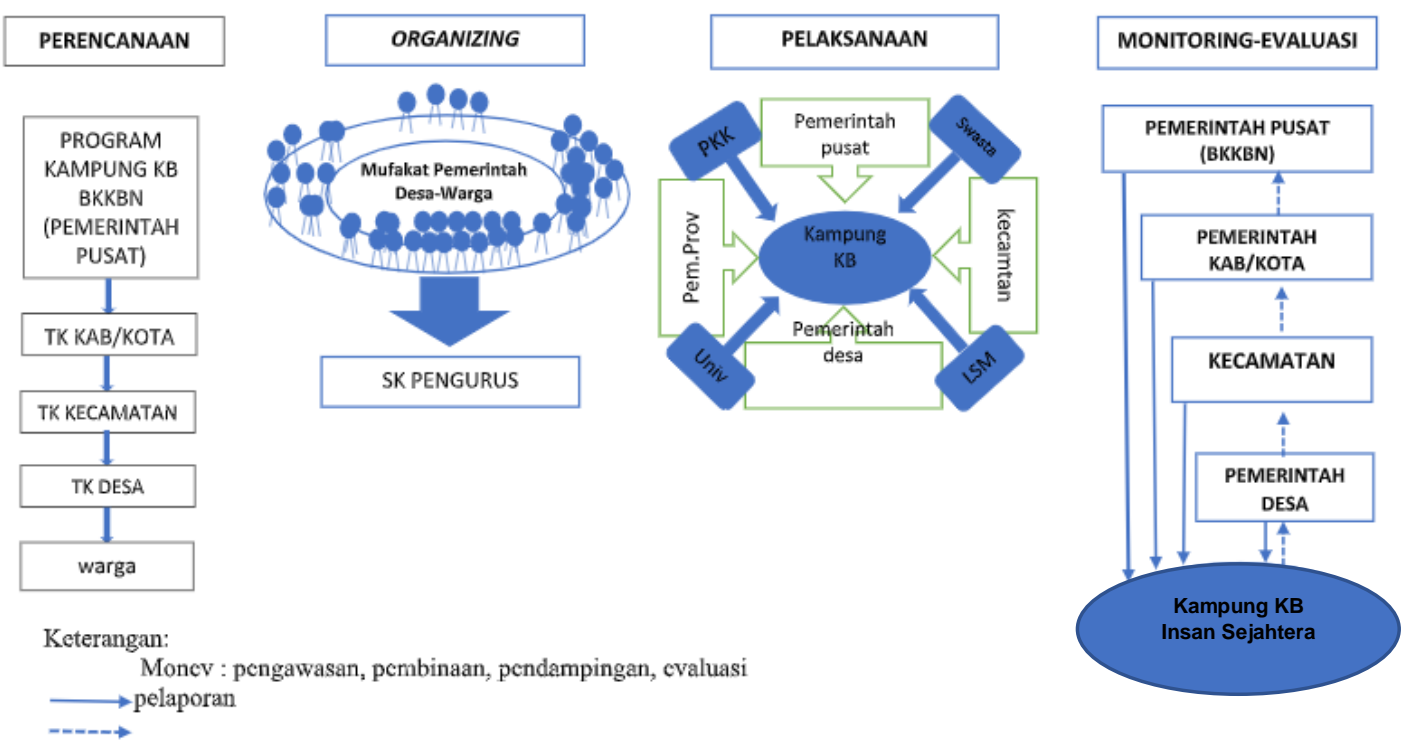

Berdasarkan data yang telah dipaparkan mengenai manajemen opinion leader dalam membangun partisipasi warga mengelola Kampung KB Insan Sejahtera, dapat dianalisis sebagai berikut: dalam tahapan perencanaan terlihat bahwa Program Kampung KB disampaikan secara hierarki dari pemerintah pusat (dalam hal ini BKKBN) sampai ke pemerintahan desa. Lalu opinion leader di tingkat desa melakukan sosialisasi program tersebut kepada warga melalui berbagai kegiatan dan acara secara intensif. Upaya sosialisasi secara tatap muka ini dirasa efektif untuk mengenalkan delapan fungsi keluarga berencana sebagau jembatan menuju kesejahteraan hidup. Pada tahapan perencanaan ini opinion leader jelas melakukan komunikasi vertikal ke bawah yang tidak bersifat instruktif, tetapi lebih merangkul dan membaur. Pola komunikasi yang diadopsi adalah pola roda dimana opinion leader yang menjadi pusat informasi, Lalu pada pengorganisasian, pemerintah desa pun lebih mengedepankan praktik-praktik komunikasi langsung, dua arah dan demokratis.

Opinion leader memperlihatkan sikap keterbukaan dengan memberikan keleluasaan sepenuhnya kepada warga untuk menentukan secara mufakat orang-orang yang akan menjadi pengurus atau pengelola Kampung KB. Upaya demokratis terlihat kental dengan adanya beberapa kali pertemuan untuk menyepakati pelaksanaan program Kampung KB. Pada tahap pengorganisasian ini, aliran komunikasi diimplementasikan bersifat dua arah, tidak saja vertikal ke bawah (dari pemerintah desa kepada warga) tapi juga vertikal ke atas (dari warga kepada pemerintah), sehingga membuat warga menjadi nyaman dan merasa diperlakukan sebagai "pemeran utama". Di sini pola komunikasi bersifat lingkaran dimana setiap warga satu sama lain bisa laing mengakses dan memberikan informasi, khususnya dalam hal penentuan siapa saja warga yang disepakati untuk menjadi pengurus. Warga satu sama lain saling memberikan masukan, argumentasi dan rekomendasi. Gaya komunikasi opinion leader cenderung mengadopsi The Equalitarian Style, dimana dalam gaya komunikasi ini, tindak komunikasi 
dilakukan secara terbuka. Artinya, setiap warga dapat mengungkapkan gagasan ataupun pendapat dalam suasana yang santai dan informal. Suasana seperti ini yang mewujudkan kesepakatan antara warga yang disahkan oleh pemimpin desa melalui SK.

Pada tahap pelaksanaan, pemerintah desa cenderung menerapkan gaya komunikasi dinamyc style, gaya dinamis yang memiliki kencenderungan agresif karena pengirim pesan atau sender memahami bahwa lingkungan pekerjaannya berorientasi kepada tindakan. Tujuan utama gaya ini adalah menstimulasi atau merangsang warga untuk terlibat aktif dan partisipatif dalam delapan program KB. Hal ini terlihat dengan upaya pemerintah desa bersinergi berbagai pihak. Bahkan pemerintah desa pun turut andil dalam berbagai kegiatan bersama warga.

Dalam tahap pengawasan dan evaluasi, pemerintah desa sebagai opinion leader senantiasa melakukannya sebagai bentuk tanggung jawab untuk membina dan mendampingi warga mencapai kehidupan sejahtera. Komunikasi yang dikembangkan bersifat dua arah, tidak saja mendapatkan laporan dari pengelola, tetapi juga memantau secara langsung dengan memimpin rapat atau mengecek ke lapangan. Untuk memperlancar proses monitoring dan evaluasi, pemerintah desa menerapkan sistem komunikasi terbuka dengan memanfaatkan berbagai sarana komunikasi. Pelaporan tidak hanya dalam bentuk formal tetapi juga secara informal seperti pelaporan melalui media "WhatsApp" pengurus ketika sedang berlangsung kegiatan. Dalam tahap ini pemerintah desa lebih terlihat menerapkan gaya structuring style yakni memanfaatkan pesan-pesan verbal secara tertulis ataupun lisan untuk memantapkan perintah yang harus dilaksanakan, penjadwalan tugas dan pekerjaan, serta struktur organisasi.

\section{Kesimpulan}

Dalam mendorong serta menumbuhkan partisipasi warga pada program-program Kampung KB, opinion leader selalu mengawali dengan proses pengenalan program kepada warga, pelibatan dan sinergi. Komunikasi yang dibangun bersifat terbuka dan demokratis. Opinion Leader selalu melibatkan warga untuk bersama-sama melakukan pengawasan terhadap pelaksanaan program. Hal ini menunjukkan adanya kepercayaan pada warga. Sikap terbuka dan percaya merupakan bagian yang menciptakan iklim komunikasi yang kondusif sehingga bisa mendorong warga menjadi kohesif dan antusias di dalam mengimplementasikan kesejahteraan melalui pelaksanaan delapan fungsi Program Kampun KB. 


\section{BIBLIOGRAFI}

Azizah, N. (2019). Strategi Kepemimpinan Kolektif Dalam Pengelolaan Program Kampung KB: Studi Deskriptif di Kampung KB Insan Sejahtera Desa Sukajaya Kec Lembang. Universitas Pendidikan Indonesia.

Barat, P. P. J. (2018). Jabar Percontohan Keberhasilan Kampung KB. https://jabarprov.go.id/index.php/news/29929/2018/09/18/Jabar-PercontohanKeberhasilan-Kampung-KB

Bogdan, R., \& Taylor, S. (1992). Pengantar Metode Kualitatif. Surabaya: Usaha Nasional.

Bryman, A. (2016). Social research methods. Oxford university press.

Creswell, J. W., \& Creswell, J. D. (2017). Research design: Qualitative, quantitative, and mixed methods approaches. Sage publications.

Moleong Lexi, J. (2000). Metodologi Penelitian Kualitatif. Remaja Posdakarya, Bandung.

Nasirin, C. (2010). Peran Strategis Pemerintah Dalam Mewujudkan Kesejahteraan Sosial. Universitas Brawijaya, Malang.

Pace, R. W., Faules, D. F., \& Mulyana, D. (2000). Komunikasi organisasi: strategi meningkatkan kinerja perusahaan. PT Remaja Rosdakarya.

Padmiati, E. (2013). Menuju Masyarakat Berketahanan Sosial melalui Pemberdayaan Lembaga Sosial Lokal di Provinsi Kalimantan Tengah. Jurnal Penelitian Kesejahteraan Sosial, 12(3), 263-275.

Sabarisman, M. (2015). Peluang dan Tantangan Pelayanan Kesejahteraan Sosial di Kabupaten Berau, Kalimantan Timur. Sosio Informa, 1(1).

Tempo.co. (2018). Dua Tahun, 8.112 Kampung KB Hadir di Indonesia. https://nasional.tempo.co/read/1124187/dua-tahun-8-112-kampung-kb-hadir-diindonesia

Wicaksono, P. E. (2018). 5 Prioritas Pembangunan Nasional pada 2019. https://www.liputan6.com/bisnis/read/3402341/5-prioritas-pembangunan-nasionalpada-2019

Yuswanto, W. (2018). Pengaruh Komunikasi Interpersonal Terhadap Kepuasan Anggota Koperasi Pegawai Republik Indonesia (KPRI)“Awi Ligar” Kabupaten Indramayu. Syntax Literate; Jurnal Ilmiah Indonesia, 3(2), 132-144. 